を溶解すると起電力は減少し，金属酸化物を溶解してい る系にさらに無水ケイ酸を添加すると起電力は上昇する ことを見いだした。

$$
\mathrm{Pt}\left(\mathrm{O}_{2}\right)\left|\mathrm{ZrO}_{2}(\mathrm{CaO})\right| \mathrm{NaCl}-\mathrm{KCl}-(\text { 金属酸化物) } \mid
$$$$
\text { 細孔を有するアルミナ|石英 } \mid \mathrm{NaCl}-\mathrm{KCl} \text { - }
$$$$
(\mathrm{AgCl} 0.27 \text { モル分率) } \mid \mathrm{Ag}
$$

（2）金属酸化物と無水ケイ酸とを溶解した $700^{\circ} \mathrm{C}$, $\mathrm{NaCl}-\mathrm{KCl}$ 等モル混合溶融塩を急冷固化した試料につ いての赤外粉体反射スペクトルを測定すると，過酸化ナ トリウム-無水々イ酸の系と酸化リチウム-無水々イ酸の 系化ついては，はっきりしたケイ酸塩化合物の生成を示 す吸收スペクトルが得られた。また，酸化第一銅と無水 タイ酸を溶解した溶融アルカリ塩化物においては第一銅 イオンは第二銅イオンに酸化される傾向があることも吸 収スペクトルから認如られた。

（3）金属酸化物の $700^{\circ} \mathrm{C}, \mathrm{NaCl}-\mathrm{KCl}$ 等モ儿混合溶融 塩への溶解度を測定して完全解離の溶解反応をするもの 上仮定して, 溶解度から算出した酸化物イオン濃度と電 池において各金属酸化物を飽和に溶解させたときの起電
力の減少との間には比例関係があることが認められた．

（4）以上の実験結果と考察上り，金属酸化物を溶解し ている $700^{\circ} \mathrm{C}, \mathrm{NaCl}+\mathrm{KCl}$ 等モル混合溶融塩に無水ケイ 酸を添加することによる電池の起電力の上昇は金属酸化 物の溶解により生成した酸化物イオンが無水々イ酸によ って捕獲され，ケイ酸アニオンが生成するためとみなさ れるとの結論に達した。

<1377> (Received April 14, 1973)

\section{文献}

1）金子吉一，児島弘直，本誌 41，347（1973）。

2) E.G. Jr. Brame, S. Cohen. J.I. Margrave, I. Inorg. and Nuclear Chem. 4, 490 (1957).

3) Sadller Index (1965).

4) D. Kumar, R.G. Ward, D.J. Williams, Discuss, Faralay Soc. 32, 147 (1961).

5) D. Hanna, J. Amer. Ceram. Soc. 46595 (1965).

6) 伊藤尚，柳分瀨兔，杉原幸夫，宫崎信義，日本金属学会誌 31, 290 (1967).

7) A.R. West, F.P. Glasser, Mat. Res. Bull. 5, 837 (1970).

8) Sadller Index (1972).

9) C.R. Masson, JISI 210, 89 (1972).

10) D. Pauer, J.P. Beck, J. Electroanal. Chem. 40, 233 (1972).

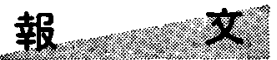

\title{
過酸化水素のカソード反応における液透過型 白金パイプモデル電極内の電位分布*
}

\author{
市野秀俊**, 山下正通**, 䆶川真男**

\begin{abstract}
of Liquid Flow-Through Porous Electrodes with Cathodic
Reaction of Hydrogen Peroxide*
\end{abstract} \\ Potential Distribution in Platinum Pipe Electrodes as a Model
}

\author{
Hidetoshi ICHINO**, Masamichi YamASHITA** \\ and Masao KUBOKAWA**
}

The potential distribution in platinum pipe electrodes with cathodic reaction of hydrogen peroxide in alkaline solution was studied as a model of liquid flow-through porous electrodes. The potential distribution was found to be affected by concentration of hydrogen peroxide, liquid flow-through rate, and especially by a specific resistance of electrolyte.

The concentration distribution of hydrogen peroxide in the electrode seems to be different from those in other solutions. Based on the results of the concentration distribution, the potential distribution as well as the concentration distribution of hydrogen peroxide, was found to change exponentially in the longitudial direction and an equation was derived on the relation between the total current and the polarization. The total current calculated by this equation was proportional to the experimental current.

Further, it was verified that the total current of the electrode was proportional to $(-\eta-R T / n F)^{1 / 2}$ under the condition of diffusion controll of the reaction, $\mathrm{Fe}^{3+}$ to $\mathrm{Fe}^{2+}$.

* 液透過型多我犋電極内の反応分布に関する研究 (第 2 報) Studies on Reaction Distribution in Liquid Flow-Through Porous Electrodes (Part 2) 昭和 44 年 5 月電気化学協会第 36 回大会 (横浜) およで昭和 46 年 5 月第38回大会 (大阪) にて発表

** 同志社大学工学部 (京都市上京区烏丸今出川東入ル) Department of Industrial Chemistry, Doshisha University (Karasuma-Imadegawa, Kamigyo-ku, Kyoto) 


\section{1 緒 言 (Introduction)}

前報1において，アルカリ水溶液中に溶解させた酸素 および過酸化水素のカソード反応について, 液透過型多 孔質炭素電極内の電位分布を実測しその電位分布に及ぼ す影響を調べた。その結果, 過酸化水素のカソード反応 に㧍いては電極内での接触分解が大きいため溶解酸素や その他の簡単な搪散支配による電位分布ではなく，電極 内での過酸化水素の濃度分布が電気化学汉応に上る濃度 分布に対して独立して存在すると考えた．また，多孔質 電極ではその構造が複雑で電極の細孔径や厚さなどの条 件を正確に限定することが困難であった，そこで，本報 では多孔質電極の最も簡単なモデルとして白金パイプを 用いてその管径, 長さを変えて過酸化水素のカソード反 㦄における白金パイプ電極内の反态分布を液を透過させ ながら調べた. すなわち, 電解液渡度や液透過流量, 過 酸化水素濃度およびその分布と電位分布上の関係を定電 流法で種々の電流密度において検討した。

この結果, 電極内の電位分布を過酸化水素の濃度分布 を考庿に入れて実験式化することができた。すなわち， 電位分布は電極内での各位置での分極の指数関数となっ た.ついで, 全電流についてこの実験式を基にして計算 した值と実験値とを比較検討した．さらに，過酸化水素 の濃度分布を基にして導いた理論式と実験結果との一致 性を調べた。

また，反応が比較的簡単で単純な拉散支配の反应上考 えられる条件で，1規定硫酸溶液中に扔髟 $\mathrm{Fe}^{3+}$ の $\mathrm{Fe}^{2+}$ ヘのカソード反応についてもその電位分布を検討 した.

\section{2 実験方法 (Experimental)}

\section{1 実酫恋置}

Fig. 1 に示した実験装置で，液留に過酸化水素を溶 かした 1 規定カセイカリ水溶液（約 $300 \mathrm{cc}$ ）二重管 で温度を一定にし，浮子式の流量計を通ってH型セルの 片方に導き，型七ルの側面の枝に白金管電極を取り付 けた。過酸化水素はアルカリ溶液中では目然分解するた め実験装置はできるだけガラス製にし気泡が器壁に付着 しないようにし，とくに電極内一気泡が入って電位測定 を困難にしないためH型せんの側面に電極を取り付汁 た.

\section{2 電 極}

直径 $2 \mathrm{~mm}$ または $3 \mathrm{~mm}$ の白金管に塩化ビニールの 管をかぶせ電極の外側に電解液がしみこまないようにし て, 白金管の所定の位置に $0.7 \mathrm{~mm}$ のをあけ，この孔 に電位分布測定のためのガラスの Luggin 毛管をそう入 しエポキシ樹脂の接着骩で固定しそれぞれ独立した酸化

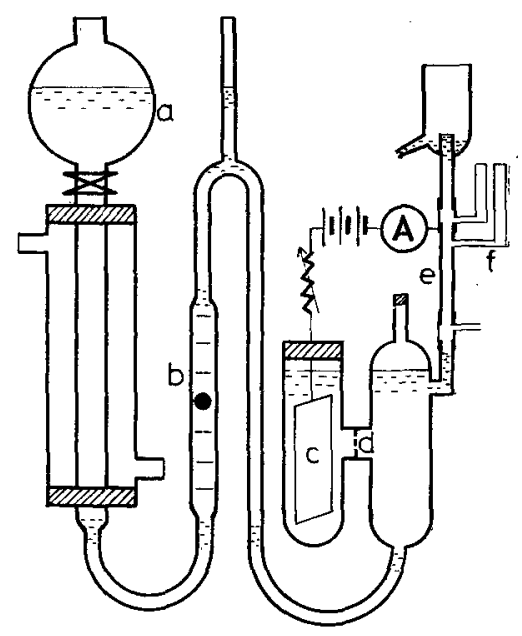

Fig. 1 Schematic diagram of the experimental apparatus

A : Ammeter, P : Recorder, a : Reservoir of electrolyte, b : Flow meter, $\mathrm{c}$ : Counter electrode, $\mathrm{d}$ : Glass filter, e : Electrode (Pt pipe) $\mathrm{f}$ : Luggin capillary with reference electrode

第二水銀照合電極に液絡した，な㧍，電解液の透過の流 れを乱さないように毛管の先は管の内部まで入れないよ らにした. 白金管の内側は $10 \mathrm{~mA} / \mathrm{cm}^{2}$ で 10 分間白金黒 メッキした.

\section{3 测定方法}

分極電位は電極前面の電位が安定となったのち電極内: の各位置の電位をロータリースイッチで順次切換えレコ 一ダーに記録させた．電解液は 1 規定カ七イカリ水溶液 に過酸化水素索 $0.01,0.03,0.05$ 規定溶加し, 過酸化水 素の濃度は電位測定の前後に電極の入口と出口の電解液 を採取し，過マンガン酸カリウムにより定量した。電解

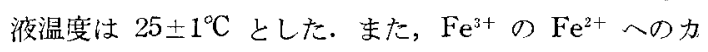
ソード反応の電位分布測定は 1 規定硫酸を用い, $\mathrm{Fe}^{3+} の$. 定量注ヨード滴定により行った.

\section{3 実験結果および考察 \\ (Results and Discussion)}

\section{1 実駼結果}

多孔質電極内の電位分布は電極の抵抗が電解液の抵抗 に比して無視できる場合, 電解液の抵抗に依存している といえる.そこで, カセイカリ濃度を $0.1,1.0,5.0$ 規 定とし電極の前面の電位をほぼ同一にした場合の電位分 布をFig. 2 に示した.なお，この図の横軸 $(z)$ は Fig. 6 の電極図に示した記号である. 電解液の抵抗が大きく なるにつれて電位分布は極端に前面にかたより，逆に小 さくなると電位分布は均一になり, 反态が電極全体に広 がり全電流は大きくなる. 以下の実験ではすべて 1 規定 


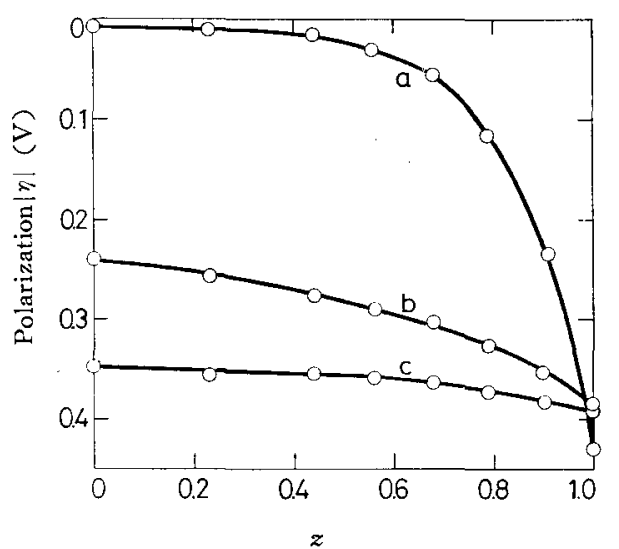

Fig. 2 Effects of $\mathrm{KOH}$ concentration on potential distribution

$r=1.5 \mathrm{~mm}, l=44 \mathrm{~mm}, v=1.0 \mathrm{cc} / \mathrm{min}, 0.03 \mathrm{~N}-\mathrm{H}_{2} \mathrm{O}_{2}$ Concentration of $\mathrm{KOH}(N)$

$\mathrm{a}: 0.1(1.7 \mathrm{~mA}), \mathrm{b}: 1.0(2.2 \mathrm{~mA}), \mathrm{c}: 5.0(2.9 \mathrm{~mA})$

カセイカリ溶液を用いた。

電極の径を $2^{\phi}, 3^{\phi}$ のものについて長さをそれぞれ変 えて電位分布を測定した結果が Fig. 3 である. 電流密 度はす心゙て同一として比較すると, 電極の長い方が分極

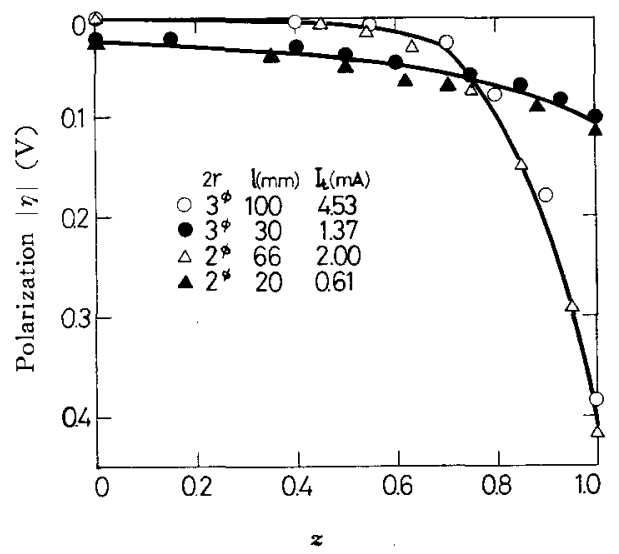

Fig. 3 Effects of $r$ and $l$ on potential distribution

$\left|I_{\mathrm{t}}\right|=0.48 \mathrm{~mA} / \mathrm{cm}^{2}, 0.03 \mathrm{~N}-\mathrm{H}_{2} \mathrm{O}_{2}, \quad v=2.0 \mathrm{cc} / \mathrm{min}$

は大きく電位分布は前面にかたよる．また，電極の長さ $l$ 亡半径 $r$ の比が同じ場合は電位分布は大体同しといえ る.これは，Fig，2でも示したよ5に電解液の抵抗に よって電位分布が支配されるといらことを示している。

Fig. 4, Fig. 5 にそれぞれ液透過流量, 電流による電位 分布の変化を示した. 当然, 液透過流量が小さく電流が 大きい場合，分極は大きくなるが電位分布は電極全体に 広がる。これは過酸化水素濃度についてを低濃度では同

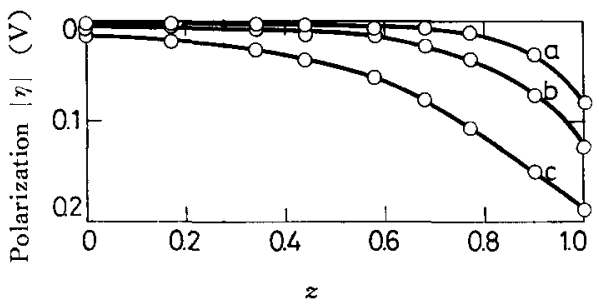

Fig. 4 Effects of flow rate on potential distribution

$r=1.0 \mathrm{~mm}, l=30 \mathrm{~mm}, 0.03 N-\mathrm{H}_{2} \mathrm{O}_{2},\left|I_{\mathrm{t}}\right|=1.20 \mathrm{~mA}$

Flow rate $(\mathrm{cc} / \mathrm{min})$

$\mathrm{a}: 2.0, \mathrm{~b}: 0.5, \mathrm{c}: 0.1$

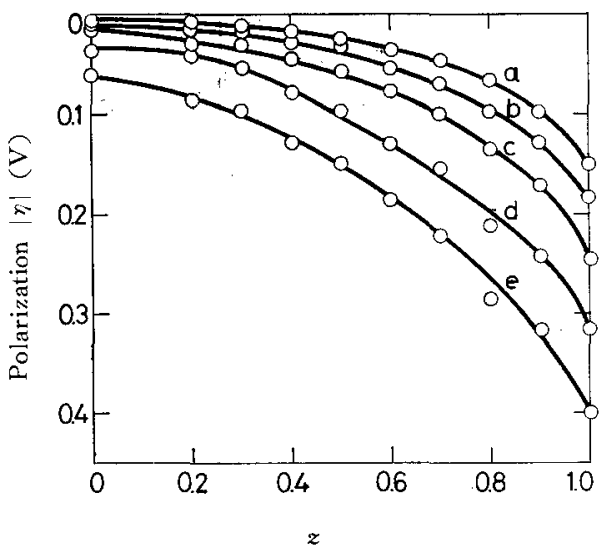

Fig. 5 Effects of total current on potential distribution

$r=1.0 \mathrm{~mm}, l=50 \mathrm{~mm}, v=0.5 \mathrm{cc} / \mathrm{min}, 0.01 \mathrm{~N}-\mathrm{H}_{2} \mathrm{O}_{2}$ Total current $\left|I_{t}\right|(\mathrm{mA})$

$\mathrm{a}: 0.75, \mathrm{~b}: 0.88, \mathrm{c}: 1.00, \mathrm{~d}: 1.13, \mathrm{e}: 1.25$

様の傾向があった。これらのことよりこの反空が搪散支 配であることを示しているといえる。

\section{2 雪位分布の解析}

いま, Fig. 6に示すような円筒形のモデル電極の半径 $r(\mathrm{~cm})$, 長さ $l(\mathrm{~cm})$ とし電極の厚さ方向を $x(\mathrm{~cm}), z=$ $x / l$ とし電極内の溶液中を流れる電流密度を $I(\mathrm{~mA} /$ $\mathrm{cm}^{2}$ ), 電気化学反応により電極面で発生する局部電流密

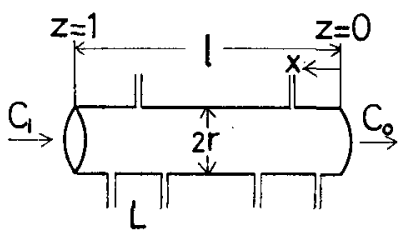

Fig. 6 Diagram of model electrode

$l$ : Length of electrode, $r:$ Radius of pipe electrode

$x$ : Distance from rear side of electrode

$z: x / l, C_{\mathrm{i}}$ : Concentration of $\mathrm{H}_{2} \mathrm{O}_{2}$ at inlet

$C_{0}$ : Concentration of $\mathrm{H}_{2} \mathrm{O}_{2}$ at outlet

$L$ : Luggin capillary with reference electrode 
度を $i\left(\mathrm{~mA} / \mathrm{cm}^{2}\right)$, 分極 $\eta(\mathrm{mV})$, 電解液の比抵抗を $\rho$ $(\Omega \mathrm{cm})$ とすると前報りで示しだように全電流 $I_{\mathrm{t}}$ と電極 前面の分極 $\eta_{l}$ の関係は ${ }^{2)}$

$$
I_{\mathrm{t}}=-2(n F C D / r \rho \delta)^{1 / 2}\left\{-\eta_{l}-(R T / n F)\right\}^{1 / 2}
$$
となる。

過酸化水素の電極内の濃度分布を知るため長さ $1.0 \sim$ $7.0 \mathrm{~cm}$ の電極について, それぞれ電極の入口と出口の 過酸化水素浱度を測定して Fig. 7 亿示した.これより， 過酸化水素濃度の対数は電極の長さ方向に対して直楾的

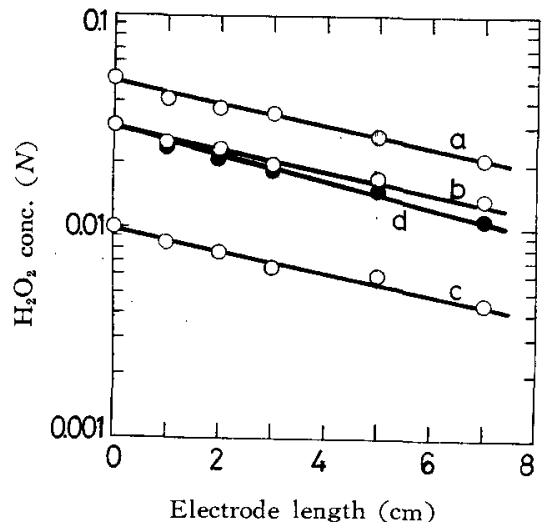

Fig. 7 Change of $\mathrm{H}_{2} \mathrm{O}_{2}$ concentration in electrode

$r=1.0 \mathrm{~mm}$

Flow rate $(\mathrm{cc} / \mathrm{min})$

$a, b, c: 0.1, d: 0.05$

に变化し，一定流量では各濃度に対してこう配は一定と なり, 流量が変化すればこう配も変化する。すなわち, 過酸化水素の接触分解はよく知られているように一次反 応 $^{3}$ であり, 電極内でも一次反応として濃度分布してい るといえる. 過酸化水素のカソード反応は平滑電極にお いてその潡度により電流一電位曲線は大きく変わり直 線 性がある゙ため，Fig. 7 の結果から Fig. 4 に扔いて分

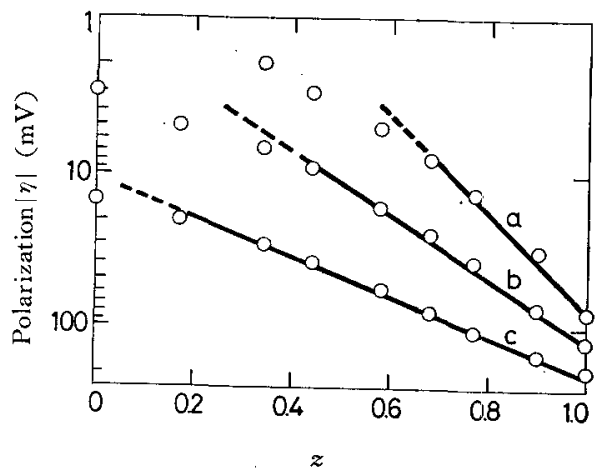

Fig. 8 The plots of $\log |\eta|-z$ $r=1.0 \mathrm{~mm}, l=30 \mathrm{~mm}, 0.03 \quad N-\mathrm{H}_{2} \mathrm{O}_{2},\left|I_{t}\right|=1.20 \mathrm{~mA}$ Flow rate $(\mathrm{cc} / \mathrm{min})$

$\mathrm{a}: 2.0, \mathrm{~b}: 0.5, \mathrm{c}: 0.1$

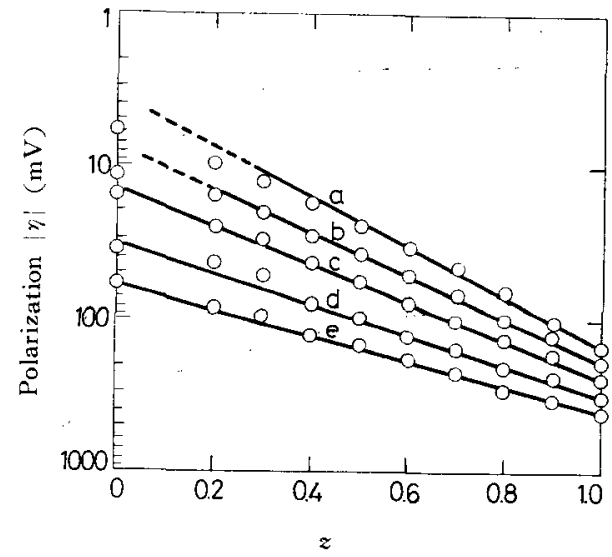

Fig. 9 The plots of $\log |\eta|-z$ $r=1.0 \mathrm{~mm}, l=50 \mathrm{~mm}, v=0.5 \mathrm{cc} / \mathrm{min}, 0.01 N-\mathrm{H}_{2} \mathrm{O}_{2}$ Total current $\left|I_{\mathrm{t}}\right|(\mathrm{mA})$

a : $0.75, b: 0.88, c: 1.00, d: 1.13$, e : 1.25

極の対数をとり Fig. 8 に示寸と電位分布は分極の対数 と直線関係にあることがわかった. Fig. 9 には電流を変 えた場合の電位分布を Fig. 8 と同様に示した. Fig. 8, Fig. 9 から分極が大きく電位分布が広がるほど, $\log \eta$ と $z$ は良い直線関倸が得られたしたがって，この関 倸を検討するため Fig. 8, Fig. 9 より

$d \log |\eta| / d z=A, \therefore d \eta \mid d z=A \eta$

ここで $A$ は Fig, 8, Fig. 9 の直線のこう配で $I_{\mathrm{t}}$ が一定 の場合定数である.また, (1) 式を導くために用いた $d \eta / d z=-\rho l I$ の関倸 $\left.{ }^{1}, 2\right)$ 飞 $(2)$ 式より

$$
A \eta=-\rho l I, \quad \therefore I_{\mathbf{t}}=-(A / \rho l) \eta_{l}
$$

したがって全電流と電極前面の分極は (3) 式で示すこ上 ができた.そこで，(3) 式を検討するため Fig. 9 の結 果において実験の電流值と (3) 式上り計算した電流值を Table 1 に示した.この表に扔いて $(A / \rho l) \eta_{l}$ と $I_{\mathrm{exp}_{\mathrm{p}}}$

Table 1 The relation between $I_{\exp }$ and $I_{\text {cal }}$

\begin{tabular}{c|c|c|c|c}
\hline & $A$ & $(A / \rho l) \eta_{t}$ & $I_{\text {cal }}$ & $I_{\text {exp }}$ \\
\hline $\mathrm{a}$ & 1.86 & 8.43 & 0.75 & 0.75 \\
$\mathrm{~b}$ & 1.39 & 9.85 & 0.88 & 0.88 \\
$\mathrm{c}$ & 1.31 & 11.9 & 1.05 & 1.00 \\
$\mathrm{~d}$ & 1.15 & 13.4 & 1.19 & 1.13 \\
$\mathrm{e}$ & 0.85 & 14.0 & 1.24 & 1.25 \\
\hline
\end{tabular}

は一致しないが，最初の值を等しいとしてこれを $I_{\mathrm{ca} a}$ と すると以下の值において $I_{\text {cal }}$ と $I_{\exp _{\mathrm{p}}}$ は良く一致した。 ここで，Aの物理的意味は明らかでないが過酸化水素濃 度, 液透過流量および電流の関数と考えられる. 結局, 過酸化水素の場合電極内の浱度分布が大きいため, 濃度 一定という（1）式の成立条件を満足しない，そこで，全 電流 $I_{\mathbf{t}}$ と電極前面の分極 $\eta_{l}$ との関倸を (1) 式の代わ りに（3）式のような害験式として定性的に示すことがで きた. 


$$
\text { つぎに（2）式より }
$$

$$
\eta=\exp (A z+B)
$$

ここで $B$ は (2) 式を積分したときの積分定数である. また，Fig. 7 で示したように電極内で過 酸化水素の濃 度は

$$
d C / d z=k C(k \text { 注定数 })
$$

ここで $z=0$ で $C=C_{0}, z=1$ で $C=C_{\mathrm{i}}$ であるから

$$
C=C_{0}\left(C_{\mathrm{i}} / C_{0}\right)^{2}
$$

限界電流に抒いては

$$
i=n F C D / \delta
$$

であるから（7）式に（6) 式を代入すると

$$
i=(n F D / \delta) C_{\mathrm{o}}\left(C_{\mathrm{i}} / C_{\mathrm{o}}\right)^{z}
$$

けま,

$$
I_{\mathrm{t}}=\int_{\mathrm{o}}^{1} i d z
$$

であるから (8) 式と (9) 式より

$$
I_{\mathrm{t}}=(n F D / \delta)\left(C_{\mathrm{i}}-C_{\mathrm{o}}\right) / \ln \left(C_{\mathrm{i}} / C_{\mathrm{o}}\right)
$$

限界電流に招いて全電流 $I_{\mathrm{t}}$ は過酸化水素の電極入口と 出口の濃度を知ることにより（10）式より算出できる.

したがって，(10）式の関係を確加めるため種々の液透 過流量に括ける限界電流と過酸化水素の濃度の関係を Fig. 10 に示した.この結果, (10) 式を満足する直線関

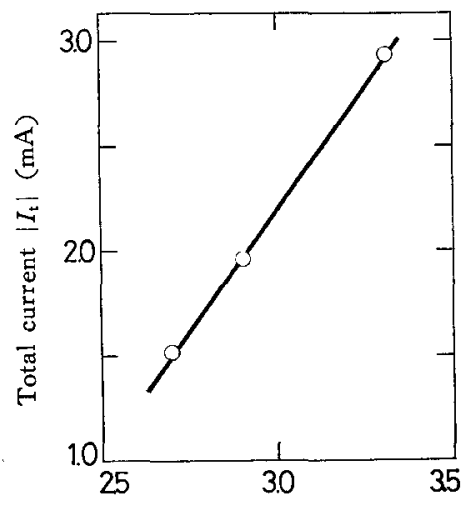

$\left(C_{\mathrm{i}}-C_{0}\right) / \log \left(C_{\mathrm{i}} / C_{0}\right) \times 10^{2}$

Fig. 10 The plots of $\left|I_{\mathbf{t}}\right|-\left(C_{\mathrm{i}}-C_{\mathrm{o}}\right) / \log$ $\left(C_{\mathrm{i}} / C_{\mathrm{o}}\right)$

$r=1.0 \mathrm{~mm}, l=30 \mathrm{~mm}, 0.03 \quad N-\mathrm{H}_{2} \mathrm{O}_{2}$

係が得られた。このように過酸化水素のカソード反応に 颃いては電極内の過酸化水素の莀度分布が一次反応に従 って分布することを考慮すると，電位分布は $\log |\eta|$ と $z$ が直線で示され，これを基にして(3)式が得られた。 この（3）式より算出された電流值は定性的に害験值とよ く一致した.

一方, 過酸化水素のように特殊な濃度分布を示すもの でなく液透過型電極でその浱度分布が電気化学反応のみ によるような反応系として1規定硫酸中での $\mathrm{Fe}^{3+}$ の $\mathrm{Fe}^{2+}$ へのカソード反応についてその電位分布を調べた.
(1) 式と $d \eta / d z=-\rho l I$ の関係より $d \eta / d z=\left(2 \rho l^{2} n F C D / r \delta\right)^{1 / 2}(\sim \eta-R T / n F)^{1 / 2}$ (11)

（11）式に打いて $z=0$ のとき $\eta=\eta_{0}$ として解くと

$$
\begin{aligned}
z= & \left(2 r \delta / n F C D \rho l^{2}\right)^{1 / 2}\left\{(-\eta-R T / n F)^{1 / 2}\right. \\
& \left.-\left(-\eta_{0}-R T / n F\right)^{1 / 2}\right\}
\end{aligned}
$$

ここで, 右辺の第二項は第一項に比して無視でき，

$|\eta| \gg R T / n F$ とすると

$$
z=\left(2 r \delta / n F C D \rho l^{2}\right)^{1 / 2}(-\eta)^{1 / 2}
$$

すなわち，一般の搪散支配の場合電位分布は (12) 式の ように分極一クの平方根として表わされることになる. そこで，この式を $\mathrm{Fe}^{3+}$ の $\mathrm{Fe}^{2+}$ へのカソード反忍につ いて調べ Fig. 11 に示すと電極の前面の部分では（12）

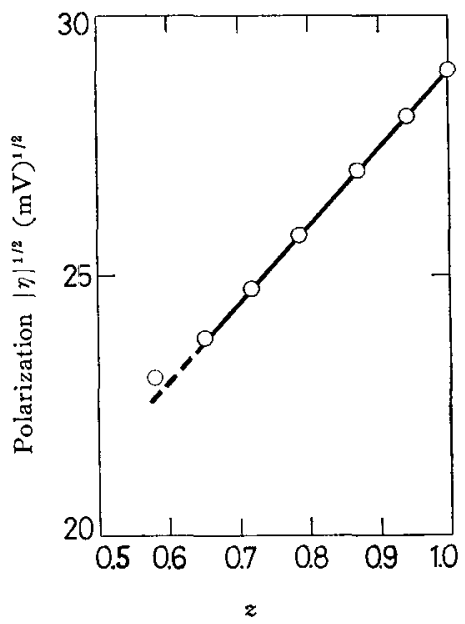

Fig. 11 The plots of $|\eta|^{1 / 2}-z$ $r=1.0 \mathrm{~mm}, l=70 \mathrm{~mm}, v=1.0 \mathrm{cc} / \mathrm{min}, 0.01$ $M / 1-\mathrm{Fe}^{8+}$

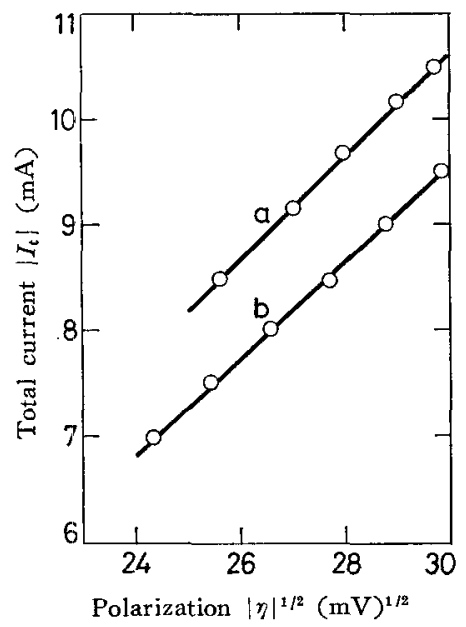

Fig. 12 The plots of $\left|I_{\mathrm{t}}\right|-\left|\eta_{l}\right|^{1 / 2}$ $r=1.0 \mathrm{~mm}, l=250 \mathrm{~mm}, 0.2 \mathrm{M} / 1-\mathrm{Fe}^{8+}$ Flow rate $(\mathrm{cc} / \mathrm{min})$ $a: 2.0, b: 1.0$ 
式の関倸が成立するといえるまた，(1) 式の関倸につ いても Fig. 12 に示すようによい直線関係が得られた。

Fig. 11, Fig. 12 の結果を検討すると電位分布はたしか に電極の前面部分 $(z=0.6 \sim 1.0)$ では (12) 式上り予想 されるよらに直線となるが, それより背面では (12) 式 を満足しない，しかし，全電流は（1）式の関係を满足し ている.このことは矛盾しているようであるが，電極内 の反応分布が前面にかたよっているため電極の背面の反 忘は前面の反応に比して小さく(1) 式の関保には誤差と なる程度だと考えると Fig. 11 とFig. 12 の関係は理解 できる.

\section{4 結 言 (Conclusion)}

過酸化水素のカソード反応における多孔質電極内の電 位分布を解析するため円筒形のモデル電極を用いて調べ た結果, 反応法搪散支配の条件で理論的解析の結果とよ
く一致することがわかった.

i) 過酸化水素の電極内の浱度 分布は一次反忘と考え られ，これを基にして電位分布は指数関数となりそのこ ら配を用いて全電流を計算することができた．さらに， 限界電流沈おいても過酸化水素の入口および出口の瀑度 より計算された電流值とよい比例性が得られた。

ii）单純な拔散支配の条件で $\mathrm{Fe}^{3+}$ の $\mathrm{Fe}^{2+}$ へのカソ 一ド反応に括ける電位分布は理論的に予想される結果と 比較的よく一致した。すなわち, 電位分布は $(-\eta)^{1 / 2}-z$ が線として表わせた。

$$
<1398>\text { (Received Aug. 8,1973) }
$$

\section{文}

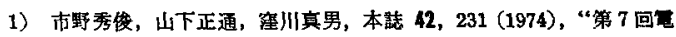
灺討論会請演要旨集”, p. 9 (1966)：“第 8 回電沘討論会講演要旨 集”" p. 32 (1967).

2) P. Ruetschi, J.B. Ockerman, J. Electrochem. Soc. 116, 1222 (1969).

3）岩合干秋，田村英雄，石野俊夫，本䌸 35, 844（1967）.

4) 岩合千秋, 田村英雄, 石野俊夫, 本誌 35, 844 (1967).

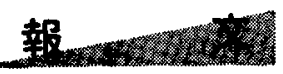

\title{
モールドICの吸水性について
}

\author{
大石敏 夫*, 羽田祐 一*
Moisture Penetration in Plastic Encapsulated
Integrated Circuits

\author{
Toshio OISHI* and Yuichi HanedA*
}

The moisture penetration in plastic molds (silicones and epoxies) using for integrated circuits was investigated. For the moisture penetration in the bulk of the plastic material, the concentration coefficient of moisture was obtained by Fick's law from the weight increase of the bulk before and after a treatment $\left(80^{\circ} \mathrm{C} 90 \%\right.$ R.H. $)$.

The weight increase of the plastic material with and without the lead frame was also measured as a function of treatment time.

These results indicated that silicone materials were reversible for the moisture penetration and were the high stability for water and that epoxy materials were irreversible for the moisture penetration and the instability for water.

Furthermore four types of modes for the moisture penetration at an interface of the lead frame and the plastic material were observed and were discussed.

\section{1 はじめに (Introduction)}

IC のパックージイング方法として従来より樹脂モー．

* 日本電気詓式会社 (川崎市中原区下沼部 1753) IC Division, Nippon Electric Company, Limited (1753, Simonumabe, Nakahara-ku, Kawasaki)
ルドがあるが、特にトランスフォーモールド方式は IC のコストダウン化, 量産化に伴い多く適用されるように なってきた.一方モールド IC の高信頼性に対しては他 のパックージに比べ而湿性が劣るを言われている.モー ルド IC の耐湿性を左右する原因の1つとしてその吸水 性が考えられその機䅺は一般的にモールド樹脂自身（バ 